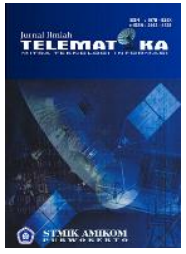

Terbit online pada laman web jurnal

http://ejournal.amikompurwokerto.ac.id/index.php/telematika/

Telematika

\title{
Pengembangan Business Intelligence Di Rumah Sakit (Studi Kasus: RSUD Prof. Dr. Margono Soekarjo Purwokerto)
}

\author{
M. Rifqi Atsani ${ }^{1}$, Galih Tyas Anjari², Nurul Mega Sarawati ${ }^{3}$ \\ ${ }^{1,3}$ Teknik Informatika \\ ${ }^{2}$ Pendidikan Teknik Informatika \\ ${ }^{1}$ Universitas Islam Indonesia Yogyakarta \\ ${ }^{2}$ Universitas Negeri Yogyakarta \\ ${ }^{3}$ Universitas Peradaban \\ Email : kya.rifky@gmail.com¹, tyasanjari21@gmail.com², nurul.mega.s@gmail.com ${ }^{3}$
}

\section{N F O A R T I K E L \\ Sejarah artikel: \\ Menerima 25 Mei 2019 \\ Revisi 24 Juni 2019 \\ Diterima 28 Agustus 2019 \\ Online Agustus 2019}

\section{Kata kunci:}

Informasi,

Rumah Sakit,

Business Intelligence,

Power BI,

System Usability Scale.

\begin{abstract}
ABSTRAK
Pemerintah memberikan tuntutan dan keharusan kepada Rumah Sakit untuk memaksimalkan sumber daya yang dimiliki supaya pelayanan lebih baik. Manajemen Rumah Sakit membutuhkan informasi yang tepat untuk dapat membuat keputusan dalam mengelola dan mengatur Rumah Sakit sesuai aturan pemerintah. Informasi yang dimiliki saat ini masih terbatas, tidak sesuai yang terjadi di lapangan, dan membutuhkan resource yang besar untuk mengumpulkan informasi karena diperoleh secara manual. Pemanfaatan teknologi informasi seperti Business Intelligence (BI) menjadi solusi karena Business Intelligence merupakan sistem yang dikembangkan untuk mengolah dan menganalisis data menjadi informasi yang bermanfaat dan memberikan dukungan untuk membantu pengambilan keputusan strategis di Rumah Sakit. Penelitian ini akan mengembangkan Business Intelligence dengan tahapan identifikasi masalah, pengumpulan data, analisis data dan pengembangan Business Intelligence, implementasi, dan evaluasi. Data yang digunakan berasal dari Sistem Informasi Rumah Sakit (SIMRS) untuk memaksimalkan evidence-based practice. Jenis pengambilan keputusan dalam penelitian ini dibatasi pada manajemen tempat tidur di rawat inap, kepatuhan dokter terhadap pelayanan atau clinical pathway, dan angka kematian di Rumah Sakit. Batasan-batasan tersebut berdasarkan hasil pengumpulan data yang terbatas pada jenis data di database dan Standar Pelayanan Mutu (SPM) Rumah Sakit yaitu Bed Occupancy Rate (BOR), Bed Turn Over (BTO), Turn Over Interval (TOI), Average Length Of Stay (ALOS), Net Death Rate (NDR), Gross Death Rate (GDR). Dashboard Business Intelligence memberikan informasi kepada manajemen jika SPM Rumah Sakit dibawah atau melebihi standar yang sudah ditetapkan oleh Kementerian Kesehatan. Nilai SPM yang dibawah atau melebihi standar mengindikasikan mutu pelayanan Rumah Sakit tidak baik sehingga manajemen harus melakukan tindakan untuk memperbaikinya. Tahapan pengembangan Business Intelligence setelah resource (sumber data, data warehouse, Power BI) tersedia adalah proses Extract, Transform, Load (ETL) dari sumber data, pengambilan data dari data warehouse menggunakan aplikasi Power BI, dan pembuatan visualisasi dashboard. Aplikasi Power BI digunakan untuk membuat dashboard Business Intelligence karena mudah digunakan dan memiliki fitur yang lebih lengkap dibandingkan aplikasi lainnya. Sistem BI harus diuji usabilitas untuk mengetahui kualitas dan kelayakan sistem sebelum digunakan secara penuh. Metode uji usabilitas atau usability testing yang digunakan adalah System Usability Scale (SUS) karena dapat digunakan pada responden yang sedikit. Kuesioner digunakan sebagai alat untuk mengetahui penilaian pengguna terhadap sistem sehingga dapat diketahui kualitas dan kelayakan sistem. Hasil akhir evaluasi sistem BI oleh manajemen Rumah Sakit mendapatkan nilai 73.18181818 dari total 11 pengguna. Nilai tersebut termasuk dalam kategori layak jika merujuk pada tabel penilaian SUS skor.
\end{abstract}




Keywords:
Information,
Hospital,
Business Intelligence,
Power BI,
System Usability Scale

Korespondensi:

Telepon: 085723454262

E-mail: kya.rifky@gmail.com

\begin{abstract}
The government gives demands and necessities to hospitals to maximize their resources to better their services. Hospital Management requires the right information to be able to make decisions in organizing and managing hospitals according to government regulations. The information hospital-owned is still limited, not match with what occurs in reality, and requires large resources to gather information because it is obtained manually. The use of information technology such as Business Intelligence (BI) is a solution because Business Intelligence is a system developed to process and analyze data into useful information and provide support to help strategic decision making in hospitals. This research will develop Business Intelligence with the first step is problem identification, data collection, data analysis and development of Business Intelligence, implementation, and evaluation. The data used comes from the Hospital Information System (SIMRS) to maximize evidence-based practice. The type of decision making in this study is limited to the management of beds in hospitalization, doctor's compliance with the service or clinical pathway, and mortality in hospitals. These limits are based on the results of data collection which is limited to the type of data in the database and the Hospital Service Quality Standards (SPM), namely Bed Occupancy Rate (BOR), Bed Turn Over (BTO), Turn Over Interval (TOI), Average Length of Stay (ALOS), Net Death Rate (NDR), Gross Death Rate (GDR). The Business Intelligence Dashboard provides information to management if the Hospital SPM is below or exceeds the standards set by the Ministry of Health. The SPM value that is below or exceeds the standard indicates that the quality of hospital services is not good so management must take action to improve it. The stages of developing Business Intelligence after resources (data sources, data warehouses, Power BI) prepared are extracted, transformed, loaded (ETL) from data sources, retrieving data from the data warehouse using the Power BI application, and creating dashboard visualization. The Power BI application was used to create Business Intelligence dashboards because it is easy to use and has more complete features than other applications. BI systems must be tested for usability to determine the quality and feasibility of the system before full use. The usability testing method used is the System Usability Scale (SUS) because it could be used on fewer respondents. The questionnaire is a tool to determine the user's assessment of the system so that the quality and feasibility of the system could be known. The final results of the BI system evaluation by Hospital management scored 73.18181818 from a total of 11 users. This value is included in the appropriate category if referring to the SUS score table.
\end{abstract}

\section{PENDAHULUAN}

Perkembangan dan penerapan teknologi informasi di bidang kesehatan terutama Rumah Sakit berjalan dengan cepat. Segala bentuk operasional dan transaksi Rumah Sakit yang awalnya manual berubah menjadi elektronik dengan memanfaatkan teknologi informasi. Transformasi ini dilakukan untuk meningkatkan pelayanan kesehatan terhadap pasien. Penerapan teknologi informasi sudah mengubah cara industri kesehatan beroperasi dan sudah membuat penggunaan sumber daya menjadi lebih efisien serta mampu meningkatkan pelayanan kesehatan di Rumah Sakit (Kruse et al., 2018). Dengan adanya perubahan ini, banyak alur pelayanan atau Standar Operasional Prosedur (SOP) yang berubah. Rumah Sakit harus meningkatkan pendapatan dan pelayanan kesehatan supaya lebih baik karena tuntutan dan keharusan Rumah Sakit untuk memaksimalkan sumber daya yang dimiliki sehingga manajemen Rumah Sakit harus melakukan tata kelola dengan baik. Informasi sangat penting bagi manajemen dan manajemen membutuhkan informasi yang tepat untuk dapat membuat keputusan dalam mengelola dan mengatur Rumah Sakit sesuai tuntutan pemerintah. Informasi merupakan aset yang organisasi sangat bergantung padanya dan kemampuan dalam mengelolanya menentukan kesejahteraan dan kesuksesan organisasi di masa depan (Azemi, Zaidi, \& Hussin, 2018). Kemampuan Rumah Sakit dalam mengelola informasi yang dimiliki dapat berarti perbedaan antara keberhasilan dan kegagalan karena informasi digunakan untuk mengontrol operasional Rumah Sakit dari hari ke hari (Azemi, Zaidi, 
\& Hussin, 2018). Peran informasi sangat penting karena memberikan informasi dalam fase pengambilan keputusan seperti perencanaan, pengendalian, dan evaluasi (Vokshi, 2017). Informasi memainkan peran yang penting dalam mengurangi keraguan dan ketidakpastian manajemen Rumah Sakit dalam mengambil keputusan. Kendala yang dihadapi manajemen RSUD Prof. Dr. Margono Soekarjo Purwokerto adalah informasi yang dimiliki saat ini masih terbatas, tidak sesuai yang terjadi di lapangan, dan membutuhkan resource yang besar untuk mengumpulkan informasi karena diperoleh secara manual. Salah satu teknologi informasi yang dapat mengolah data dan memberikan informasi yang dibutuhkan oleh organisasi adalah Business Intelligence (BI). Business Intelligence merupakan aplikasi, infrastruktur, dan alat yang memungkinkan akses dan analisis informasi untuk meningkatkan dan mengoptimalkan pengambilan keputusan dan kinerja organisasi (Gaardboe, Nyvang, \& Sandalgaard, 2017). Menurut (Llave, 2019), Business Intelligence adalah kumpulan metodologi, proses, arsitektur, dan teknologi yang mengubah data mentah menjadi informasi yang berguna dan bermanfaat dan memungkinkan pengguna untuk membuat keputusan bisnis dengan data real time. Business Intelligence telah menerima pengakuan luas di dunia bisnis sebagai alat untuk mengatasi masalah besar terkait data, untuk membantu manajemen memahami bisnis mereka dan untuk membantu mereka dalam membuat keputusan yang efektif (Trieu, Cockcroft, \& Perdana, 2018). Business Intelligence juga memfasilitasi dan mendukung "grounded actions" dalam organisasi (Eidizadeh, Salehzadeh, \& Esfahani, 2017). Peningkatan hubungan dengan mitra organisasi dan peningkatan pendapatan merupakan bukti sebab akibat penggunaan BI, yang secara terus menerus mengarah pada pertumbuhan pendapatan dan peningkatan daya saing (Mavi \& Standing, 2018). Business Intelligence menjadi salah satu solusi supaya manajemen RSUD Prof. Dr. Margono Soekarjo Purwokerto mendapatkan informasi yang tepat dan cepat untuk membantu pengambilan keputusan strategis di Rumah Sakit. Business Intelligence (BI) belum banyak diterapkan di Rumah Sakit di Indonesia. Beberapa penelitian sebelumnya yang menjadi bahan rujukan dan pertimbangan adalah pengembangan Business Intelligence di Semen Padang Hospital dengan menggunakan metode BI Road Map dan OLAP (Silvana, Ricky, \& Derisma, 2017). Business Intelligence di Semen Padang Hospital dikembangkan dalam 6 fase yaitu Justification, Planning, Business Analysis, Design, Construction, dan Deployment. Penelitian lainnya adalah perancangan Executif Information System (EIS) untuk evaluasi kinerja pelayanan dengan menggunakan metode OLAP di RSUP Mohammad Hoesin Palembang. Penelitian tersebut menyimpulkan bahwa informasi yang dibutuhkan untuk evaluasi kinerja pelayanan yaitu nilai statistik Rumah Sakit yang terdiri dari BOR, LOS, BTO, TOI, ALOS, GDR, dan NDR dan EIS berhasil mengeluarkan informasi nilai statistik Rumah Sakit (Izhariman, Darwiyanto \& Puspitasari, 2017). Rumah Sakit harus dapat melakukan perencanaan atau manajemen yang baik dan pengambilan keputusan yang tepat terhadap operasional supaya pelayanan Rumah Sakit terhadap masyarakat meningkat.

RSUD Prof. Dr. Margono Soekarjo (RSMS) merupakan Rumah Sakit tipe B yang berlokasi di kota Purwokerto. RSUD ini sudah menerapkan Sistem Informasi Manajemen Rumah Sakit (SIMRS) sejak tahun 2008. Salah satu komponen dari SIMRS adalah Rekam Medik Elektronik (RME). Rekam Medik Elektronik adalah bentuk digital dari catatan pasien yang mencakup informasi pasien seperti identitas pasien, medis pasien, riwayat penyakit, alergi, hasil pemeriksaan, dan rencana perawatan (Kruse et al., 2018). Ketika data-data tersebut (termasuk data dari dokter, perawat, dan farmasi) dikumpulkan, data tersebut sudah dapat dikategorikan sebagai Big Data (Lee \& Yoon, 2017). Big Data 
ini dapat dimanipulasi dan dianalisis untuk mengidentifikasi pola, dan tren sehingga ada kemungkinan tak terbatas untuk menghasilkan pengetahuan baru dengan menganalisis hubungan antar data tersebut (Vayena et al., 2018). Business Intelligence digunakan sebagai alat untuk memanipulasi dan menganalisis data-data dalam SIMRS dan RME sehingga menjadi informasi yang berguna untuk pengambilan keputusan. Business Intelligence dapat mempengaruhi pengambilan keputusan dalam hal ketepatan waktu (BI mampu memberikan pengetahuan dan informasi yang dibutuhkan sehingga pengambilan keputusan dapat dilakukan sesuai dengan kebutuhan), kepercayaan diri (dukungan data yang diberikan meningkatkan kemampuan untuk mengambil keputusan), dan hasil (meningkatkan kesadaran terhadap konsekuensi dari keputusan yang diambil, mengurangi biaya atau pengeluaran, dan dapat mengukur output pelayanan terhadap pasien) (Loewen, 2017). Tools yang dapat digunakan untuk membangun dashboard BI banyak jenisnya. Perlu memperhatikan beberapa hal dalam menentukan tool yang akan digunakan untuk membangun BI antara lain dukungan terhadap infrastruktur yang ada, kegunaannya, pricing, dan scalability (Gowthami \& Kumar, 2017). Analisis statistik dan visualisasi data sangat penting untuk diperhatikan ketika mengkomunikasikan tampilan dan data yang digunakan (Cheng et al., 2018). Dalam penelitian kali ini, tool yang digunakan adalah Power BI karena Power BI memiliki fitur yang lebih lengkap seperti dapat ditampilkan secara online baik melalui desktop, web, dan mobile, memiliki visualisasi yang lengkap, dapat menggunakan Data Connectivity Gateways sehingga dapat mengakses data langsung, dan dapat terhubung secara real-time dengan sumber data.

Tujuan penelitian ini adalah membangun sistem Business Intelligence untuk membantu pengambilan keputusan di RSUD Prof. Dr. Margono Soekarjo Purwokerto. Batasan masalah dalam penelitian ini adalah BI hanya akan menampilkan visualisasi yang membantu 3 macam pengambilan keputusan. Pengambilan keputusan tersebut adalah pengambilan keputusan terkait manajemen tempat tidur di rawat inap, kepatuhan dokter terhadap standar pelayanan (LOS) atau clinical pathway, dan pantauan terhadap angka kematian. Beberapa indikator yang digunakan dalam menyusun visualisasi tersebut antara lain indikator Standar Mutu Pelayanan (SPM) Rumah Sakit yang meliputi BOR, LOS, BTO, TOI, ALOS, GDR, dan NDR. Data-data yang diambil merupakan data-data yang berkaitan dengan batasan masalah. Indikator-indikator Standar Mutu Pelayanan (SPM) Rumah Sakit ada di pedoman SIRS terbitan Kementerian Kesehatan Republik Indonesia. Penelitian ini bertujuan mengembangkan Business Intelligence untuk membantu manajemen RSUD Prof. Dr. Margono Soekarjo Purwokerto dalam mengambil keputusan. Masalah yang dialami oleh pihak manajemen dalam mengambil keputusan terkait kebijakan dan aturan di Rumah Sakit adalah kurangnya data dan informasi yang cepat dan tepat. Business Intelligence yang dikembangkan diharapkan mampu membantu memberikan pengetahuan untuk membantu manajemen RSUD Prof. Dr. Margono Soekarjo Purwokerto dalam mengambil keputusan dan menjadi bahan pertimbangan bagi RSUD Prof. Dr. Margono Soekarjo Purwokerto untuk dapat menerapkan sistem Business Intelligence kedepannya.

\section{METODE PENELITIAN}

Metode penelitian yang digunakan adalah metode penelitian kuantitatif. Penelitian ini menggunakan dua jenis data yakni primer dan sekunder. Data primer diperoleh dari hasil kuesioner. Data sekunder diperoleh dari kajian pustaka.

\section{Tinjauan Pustaka}


a. Business Intelligence

Business Intelligence merupakan sistem yang digunakan untuk menganalisis data dan mengolahnya menjadi informasi untuk membantu pengambilan keputusan proses bisnis. BI juga dapat meningkatkan nilai data dan informasi organisasi dengan mengintegrasikan seluruh data sehingga menghasilkan pengambilan keputusan yang lengkap (Silvana, Ricky, \& Derisma, 2017). Langkah-langkah pengembangan Business Intelligence secara umum dapat dilihat pada gambar 1 .

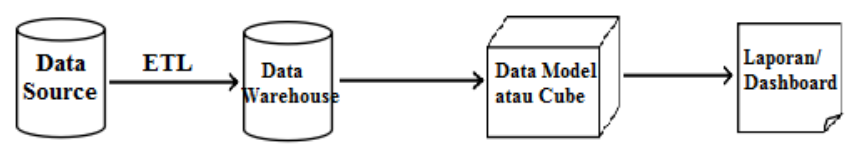

Gambar 1. Langkah-langkah Pengembangan BI

1) Data Source

Merupakan sumber data yang akan digunakan untuk membuat data warehouse. Sumber data dapat berupa database (SQLServer, Oracle, PostgreSQL, dan MySQL) dan file (file excel, csv, $x m l$, dan json).

2) ETL

Merupakan proses pengolahan atau penyaringan data dari database transactional ke data warehouse.

3) Data Warehouse

Data warehouse merupakan database yang dibuat untuk analisis dan pelaporan. Beberapa model yang biasa digunakan dalam pembuatan data warehouse adalah model skema bintang dan skema snowflake.

4) Data Model

Metode yang digunakan untuk menganalisis data dari data warehouse secara multidimensi.

\section{5) Dashboard}

Bentuk visualisasi data dalam bentuk teks atau grafik.

\section{b. Power BI}

Power BI merupakan aplikasi pembuatan Business Intelligence yang dimiliki oleh Microsoft yang mampu menampilkan visualisasi data, memungkinkan membuat query, koneksi data, dan laporan. Konsep sistem kerja dalam aplikasi Power BI ada 3 yaitu datasets, report, dan dashboard.

c. SQLServer

Microsoft SQLServer merupakan sistem manajemen basis data relasional yang dikembangkan oleh Microsoft. Salah satu fitur yang dimiliki SQLServer yang dapat digunakan untuk pengembangan Business Intelligence adalah SQLServer Integration Services (SSIS).

\section{Alat dan Bahan}

Resource atau kebutuhan yang digunakan untuk pengembangan Business Intelligence di RSUD Prof. Dr. Margono Soekarjo Purwokerto adalah Server spesifikasi System X3650 M5 Rack Server, Database SQLServer 2008 R2, Aplikasi Power BI desktop versi 2.67.5404.801, Laptop HP Probook 440 G3 dengan Operating System Windows 7 Professional 64-bit dengan RAM 4 GB, dan Kuesioner Evaluasi. 


\section{Tahapan Pengembangan Business Intelligence}

Pengembangan Business Intelligence pada penelitian ini mengikuti tahapan identifikasi masalah, pengumpulan data, analisis data dan perancangan Business Intelligence, implementasi, dan evaluasi. Tahapan pengembangan Business Intelligence dapat dilihat pada gambar 2.

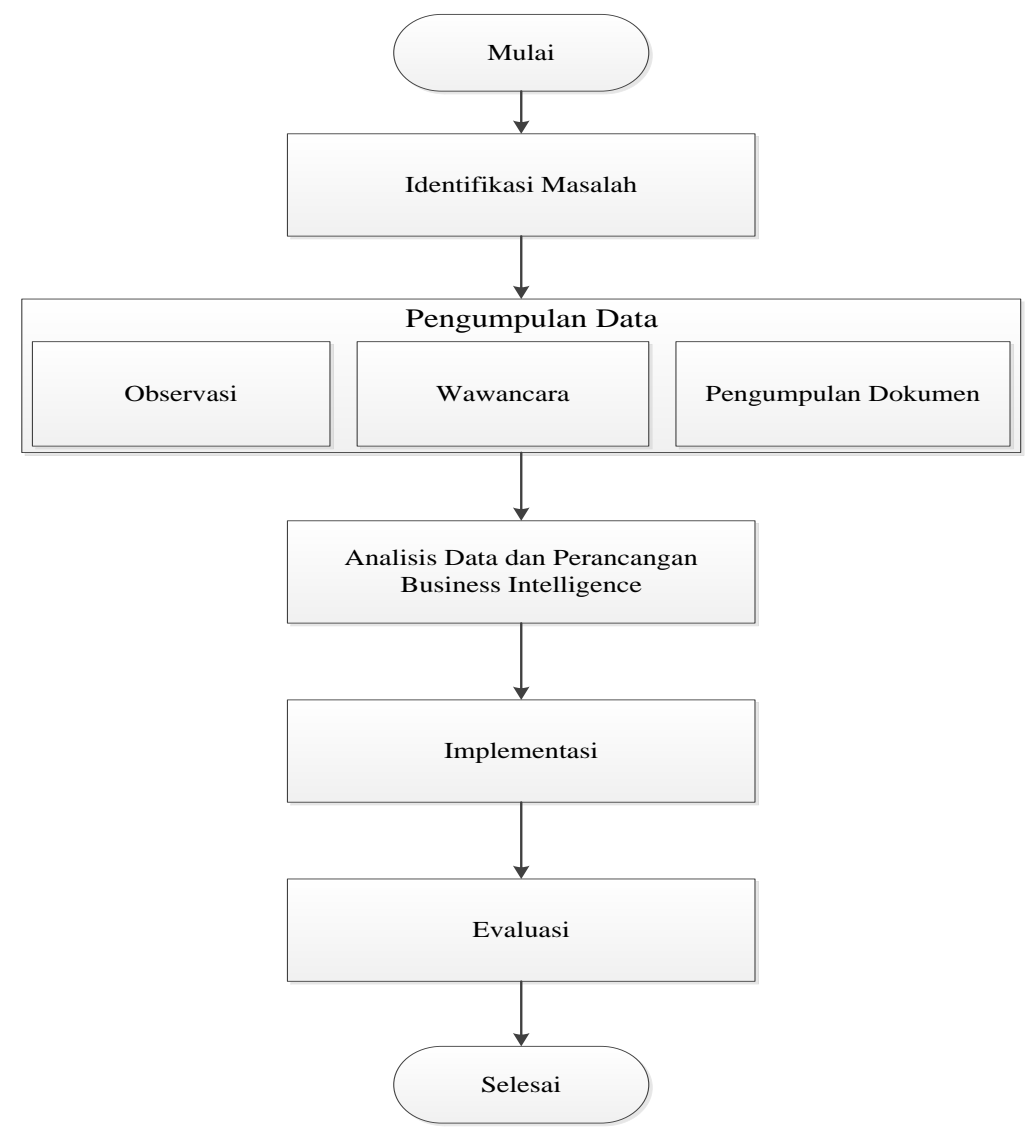

Gambar 2. Tahapan Pengembangan Business Intelligence

Penjelasan tahapan-tahapan pengembangan Business Intelligence di RSUD Prof. Dr. Margono

Soekarjo Purwokerto adalah sebagai berikut:

a. Identifikasi Masalah

Identifikasi masalah merupakan langkah awal yang dilakukan untuk mengetahui permasalahan yang ada. Masalah yang dialami oleh pihak manajemen dalam mengambil keputusan terkait kebijakan dan aturan di Rumah Sakit adalah kurangnya data dan informasi yang cepat dan tepat. Informasi sangat penting bagi manajemen karena sebagai pendukung manajemen dalam membuat keputusan. Informasi yang dimiliki saat ini masih terbatas, tidak sesuai yang terjadi di lapangan, dan membutuhkan resource yang besar untuk mengumpulkan informasi karena diperoleh secara manual. Informasi yang dibutuhkan manajemen seharusnya dapat diperoleh dari Sistem Informasi Rumah Sakit (SIMRS). SIMRS dapat digunakan sebagai sumber data utama karena sistem ini sudah berjalan sejak tahun 2008.

b. Pengumpulan Data

Dalam tahap ini, peneliti menggunakan beberapa sumber data untuk digunakan sehingga kualitas penelitian dapat teruji. Sumber data yang digunakan adalah sebagai berikut:

1) Observasi 
Pengumpulan data melalui observasi berupa hasil pengamatan peneliti di lapangan. Hasil pengamatan menghasilkan masalah yang menjadi latar belakang penelitian ini.

2) Wawancara

Pengumpulan data dengan wawancara merupakan salah satu metode yang digunakan untuk memperoleh data dan informasi dari narasumber secara langsung atau lisan. Wawancara dilakukan kepada staf bagian sistem informasi di RSMS dan kepala bidang pelayanan sebagai bagian yang bertanggung jawab terhadap pelayanan di Rumah Sakit. Hasil yang didapatkan dari kepala bagian pelayanan adalah standar indikator mutu pelayanan Rumah Sakit yaitu BOR, LOS, BTO, TOI, ALOS, GDR, dan NDR. Standar ini dipakai sebagai indikator nilai dalam dashboard BI. Hasil wawancara dengan bagian sistem informasi adalah izin penggunaan database Rumah Sakit, pembuatan data warehouse di database server, penggunaan fitur SQLServer Integration Services (SSIS) di SQLServer, dan macam data yang dapat digunakan untuk menyusun dashboard BI. Data-data yang dapat digunakan adalah data pasien, data transaksi pasien rawat inap, data diagnosa, data lama perawatan, dan lain-lain.

3) Pengumpulan Dokumen

Pengumpulan dokumen dilakukan dengan mengambil data yang terdapat pada basis data sumber di dalam database server. Data yang diambil adalah data yang diperlukan sesuai dengan arahan dari bagian sistem informasi selama tahap wawancara. Selain itu, pengumpulan dokumen juga terkait dengan mempelajari SPM Rumah Sakit yang akan digunakan sebagai standar indikator pengambilan keputusan.

c. Analisis Data dan Perancangan Business Intelligence

Data-data yang sudah dikumpulkan dianalisis untuk dipetakan dalam pembuatan dashboard Business Intelligence. Berdasarkan pengumpulan data, diperoleh kebutuhan informasi untuk pengembangan Business Intelligence di RSUD Prof. Dr. Margono Soekarjo diantaranya informasi jumlah pasien dan tempat tidur (berdasarkan ruang rawat inap), informasi nilai indikator Bed Occupancy Rate (BOR), Bed Turn Over (BTO), Turn Over Interval (TOI), Average Length Of Stay (ALOS), Net Death Rate (NDR), dan Gross Death Rate (GDR) berdasarkan ruang rawat inap, informasi ALOS untuk diagnosa clinical pathway (berdasarkan diagnosa Batu Ureter, Hiperbilirubin, CA Ovarium, Pre Eclamsia Berat, dan Unstable Angina Pactoris), dan informasi 10 jumlah diagnosa penyebab kematian terbanyak. Informasi ini dapat diperoleh dengan menggunakan sumber data dari database live DBRS_MARGONO. Tahapan perancangan Business Intelligence dapat digambarkan dengan arsitektur fisik. Arsitektur fisik menggambarkan konfigurasi atau konsep pengembangan sistem Business Intelligence. Arsitektur fisik dibangun dengan berdasarkan tahapan-tahapan pengembangan Business Intelligence yang dijelaskan pada gambar 1. Arsitektur fisik pengembangan Business Intelligence di RSUD Prof. Dr. Margono Soekarjo Purwokerto dengan menggunakan Power BI dapat dilihat pada gambar 3. 


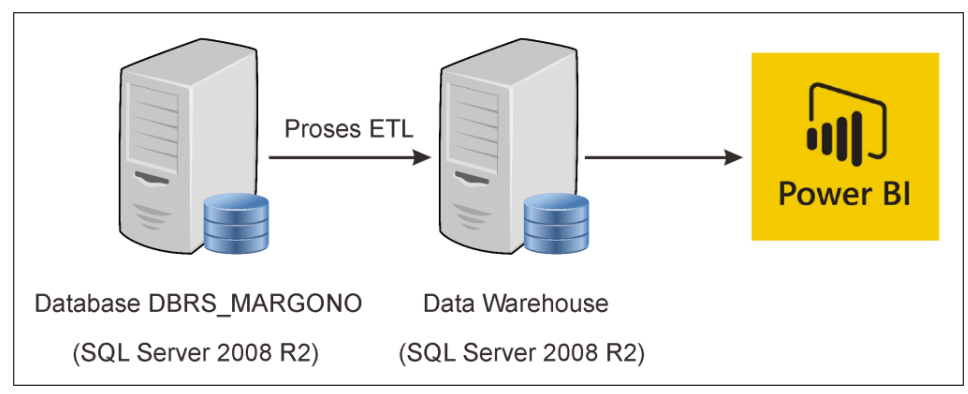

Gambar 3. Langkah-langkah Pengembangan Business Intelligence

Berdasarkan arsitektur tersebut, pengembangan BI dapat dijelaskan dalam 3 tahap yaitu pemodelan data warehouse, proses ETL, dan proses visualisasi dashboard Power BI.

\section{1) Pemodelan Data Warehouse}

Perancangan arsitektur data warehouse merupakan perancangan model database untuk menampung data-data transactional dari database sumber. Data warehouse dalam penelitian ini dibuat menjadi 2 yaitu dw_bangsal dan dw_penyakit. Skema dan relasi untuk data warehouse rawat inap (bangsal) dan penyakit dapat dilihat pada gambar 4 .

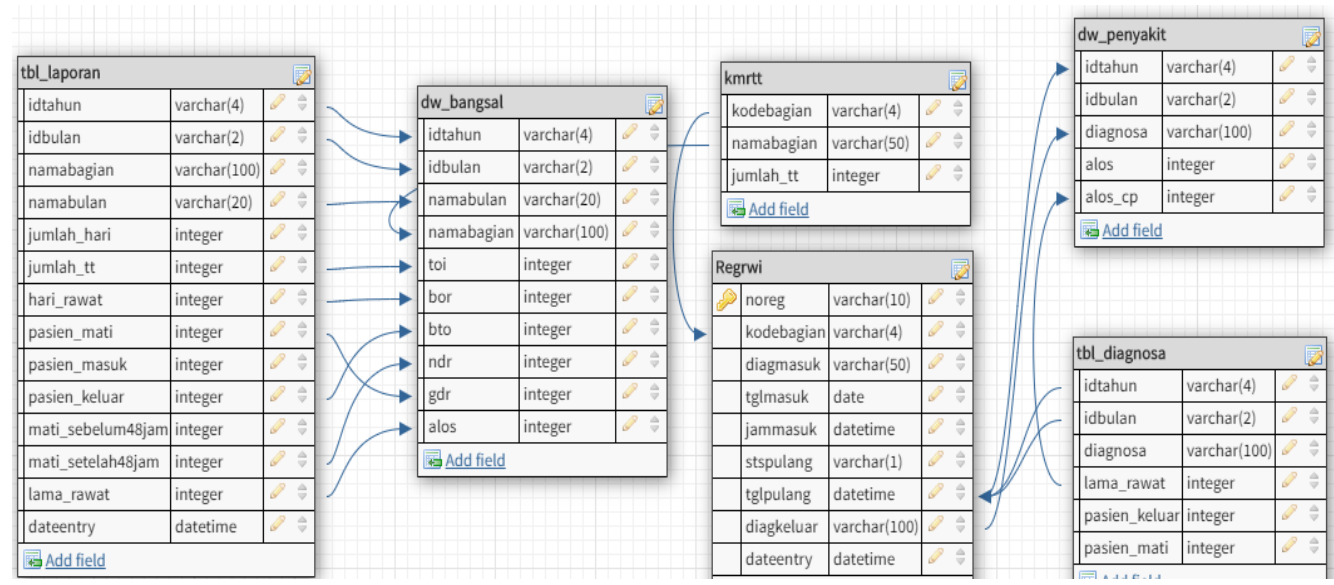

Gambar 4. Skema Data Warehouse rawat inap (bangsal) dan penyakit

2) Proses Extract, Transform, dan Load (ETL)

ETL merupakan proses pemindahan data dari database sumber (OLTP) ke data warehouse (OLAP). Proses ETL menggunakan fasilitas SQLServer yaitu SQLServer Integration Services (SSIS). Proses ETL dilakukan terhadap 4 tabel dimensi yaitu tabel kmrtt, tbl_diagnosa, tbl_laporan, dan regrwi, dan 2 tabel fakta yaitu tabel dw_bangsal dan dw_penyakit.

3) Visualisasi dashboard BI

Dashboard BI akan dibuat berdasarkan jenis pengambilan keputusan yang telah ditentukan. Dashboard manajemen tempat tidur berisi indikator BOR, BTO, TOI, dan jumlah pasien menginap. Dashboard kepatuhan dokter terhadap pelayanan berisi indikator ALOS total dan ALOS untuk diagnosa clinical pathway. Dashboard pantauan angka kematian berisi indikator NDR, GDR, dan 10 penyakit penyebab kematian terbanyak. Dalam menyusun perancangan visualisasi dashboard di Power BI, langkah-langkah yang dilakukan peneliti adalah koneksi ke sumber data, pemilihan data dan visualisasi, dan pengaturan tata letak.

d. Implementasi 
Tahap ini merupakan tahap uji coba penggunaan sistem Business Intelligence sebelum digunakan secara penuh oleh manajemen Rumah Sakit. Manajemen melihat dan menjalankan dashboard BI dengan dipandu teknisi sehingga dapat menilai kualitas sistem nantinya. Waktu pelaksanaan ujicoba dilakukan secara bersama-sama di aula dengan menggunakan komputer atau smartphone masing-masing manajemen. Uji coba dilakukan selama 4 kali dalam 1 bulan dan bagi manajemen yang berhalangan hadir menugaskan yang lain untuk menggantikan.

\section{e. Evaluasi}

Evaluasi yang akan dilakukan adalah uji usabilitas sistem karena metode ini merupakan metode yang paling tepat digunakan untuk menilai sistem sebelum digunakan secara penuh. Uji usabilitas akan menggunakan metode System Usability Scale (SUS). Alat yang digunakan untuk melakukan evaluasi adalah kuesioner SUS yang memiliki 10 pertanyaan. Metode perhitungan metode SUS akan dijelaskan dalam bab pembahasan. Hasil akhir perhitungan akan menghasilkan nilai antara 0-100. Selanjutnya, nilai tersebut dibandingkan dengan tabel SUS score seperti pada gambar 5. Sistem dapat masuk dalam kategori baik jika memiliki nilai akhir $>=70$.

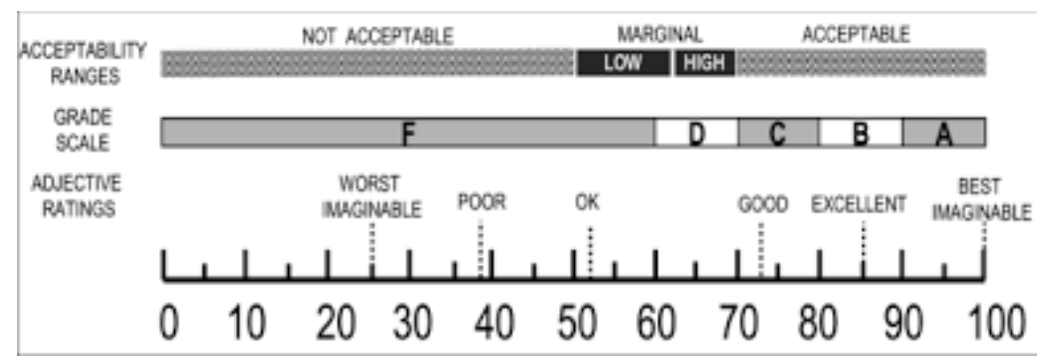

Gambar 5. Grafik Percentile Rank Penilaian SUS Score

\section{Subjek dan Objek Penelitian}

Penelitian ini dilakukan di RSUD Prof. Dr. Margono Soekarjo Purwokerto selama bulan Januari 2019 sampai Mei 2019. Setiap tahapan pengembangan dilakukan selama periode tersebut. Subjek penelitian yang akan menggunakan sistem Business Intelligence adalah manajemen Rumah Sakit atau pejabat struktural sebanyak 11 orang yang terdiri dari Direktur, Wakil Direktur Pelayanan dan Kerja sama, Wakil Direktur Penunjang dan Pendidikan, Wakil Direktur Umum dan Keuangan, Kepala Bidang Pelayanan, Kepala Bidang Keperawatan, Kepala Bidang Umum, Kepala Bidang Penjamin Mutu dan Kerja sama, Kepala Bidang Penunjang Medis, Kepala Bidang Penunjang Sarana dan Prasarana, dan Kepala Bidang Perencanaan. Pejabat-pejabat yang dipilih merupakan pejabat yang memiliki keterkaitan dengan pengambilan keputusan yang sudah ditentukan dalam penelitian ini. Objek dalam penelitian ini adalah sistem Business Intelligence yang telah dikembangkan.

\section{HASIL DAN PEMBAHASAN}

Penggunaan teknologi informasi sejalan dengan misi Rumah Sakit yang terakhir yaitu mengembangkan sistem manajemen yang handal, transparan, akuntabel, efektif, dan efisien. Sampai penelitian ini dilakukan, RSMS belum miliki Executive Information System (EIS) dan belum ada rencana pengembangan sebuah sistem atau aplikasi yang masuk dalam kategori EIS karena masih fokus 
pengembangan SIMRS dan Rekam Medik Elektronik di bagian-bagian lain yang belum menggunakan sistem elektronik. Business Intelligence yang dikembangkan dalam penelitian ini merupakan EIS pertama yang dibuat menggunakan data transactional di SIMRS. Penerapan BI perlu memperhatikan beberapa hal supaya berhasil antara lain keterampilan manajemen, dukungan manajemen, keterlibatan pengguna, lingkungan eksternal, manajemen proses, strategi dan visi, organisasi, dan kompetensi dalam pengembangan (Gaardboe \& Svarre, 2017). Manajemen yang ingin meningkatkan kinerja organisasi harus menggunakan BI dan untuk memaksimalkannya tidak menggunakan cara tradisional yang membatasi pengumpulan dan penyimpanan data di database normal (Abusweilem \& Abualous, 2019). Power BI dapat memaksimalkan sistem BI karena interkoneksi dengan database terjadi secara langsung, jika terjadi perubahan data di database, maka secara otomatis informasi di dashboard Power BI akan berubah.

Langkah pertama dalam pengembangan BI yaitu melakukan proses ETL. Selama proses berlangsung, akan terjadi konversi data, pemetaan ulang data, dan perubahan data dengan cara tertentu (Khedr, Kholeif, \& Saad, 2017). Data berasal dari 4 tabel dimensi yaitu tabel kmrtt, tbl_diagnosa, tbl_laporan, dan regrwi akan di extract, selanjutnya transform ke data yang dibutuhkan dan kemudian di load ke tabel fakta dw_bangsal dan dw_penyakit di data warehouse. Proses ETL atau denormalisasi database ini dapat dilakukan secara otomatis dengan menggunakan fitur SSIS atau Agent SQLServer. Proses ETL ini menggunakan query SQLServer yang biasa digunakan seperti select dan insert. Langkah kedua, aplikasi Power BI dihubungkan ke data warehouse dan mengambil data dari tabel fakta yang tersedia. Proses ini dapat dilakukan langsung ke database karena Power BI mendukung koneksi langsung ke database SQLServer. Langkah terakhir adalah membuat dashboard visualisasi untuk membantu pengambilan keputusan seperti terlihat pada gambar 6, 7, dan 8 dengan menggunakan Power BI. Informasi yang ditampilkan dalam dashboard visualisasi di Power BI dikelompokkan berdasarkan dengan kriteria pengambilan keputusan yang sudah ditentukan yaitu dashboard pengaturan tempat tidur di rawat inap, dashboard kepatuhan dokter terhadap pelayanan atau clinical pathway, dan dashboard pantauan terhadap angka kematian. Visualisasi yang digunakan berupa grafik, tachometer, tabel, bar chart, dan teks. Visual yang paling mencolok adalah tachometer karena dikategorikan menggunakan warna, warna merah menunjukkan indikator memiliki nilai yang tidak ideal dan untuk nilai ideal ditampilkan dengan warna hijau. Gambar 6 merupakan visualisasi dashboard untuk pengaturan tempat tidur di rawat inap. Indikator yang ditampilkan adalah Bed Occupancy Rate (BOR), Bed Turn Over (BTO), Turn Over Internal (TOI), dan informasi jumlah pasien selama 1 bulan. Indikator BOR,TOI dan BTO jika nilainya lebih dari nilai ideal, manajemen dapat memepertimbangkan untuk menambah jumlah tempat tidur dan sebaliknya jika nilainya rendah. Jumlah pasien secara periodik atau harian, dapat memberikan gambaran ketika jumlah pasien mendekati jumlah tempat tidur, atau sudah melebihi batasnya. 


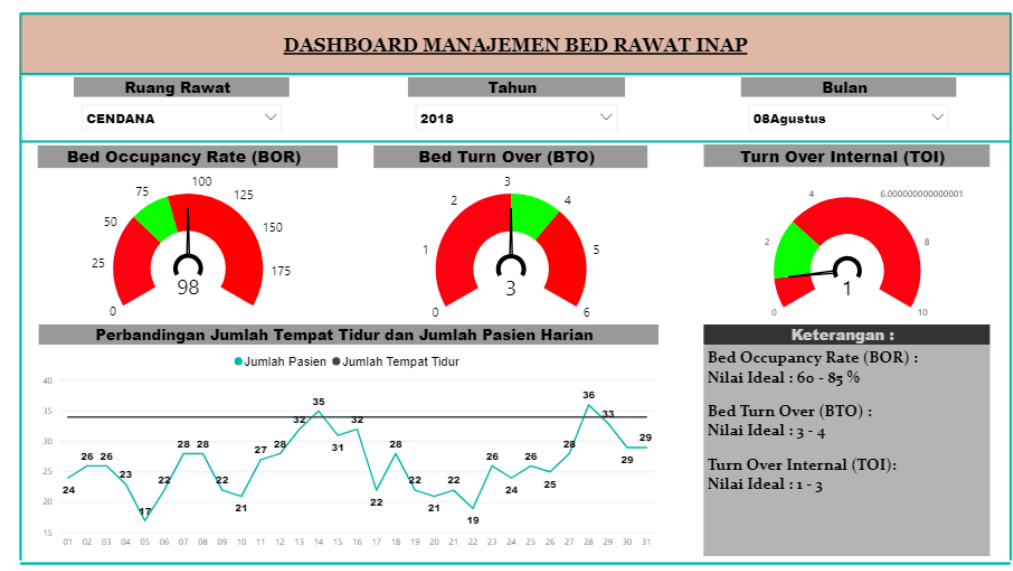

Gambar 6. Dashboard Manajemen Tempat Tidur

Dashboard untuk mengetahui kepatuhan dokter terhadap pelayanan (LOS) atau clinical pathway ditunjukkan pada gambar 7. Indikator yang ditampilkan adalah Average Length Of Stay (ALOS), dan informasi nilai ALOS untuk diagnosa Batu Ureter, Hiperbilirubin, CA Ovarium, Pre Eclamsia Berat, dan Unstable Angina Pactoris. Lama perawatan untuk diagnosis tertentu sudah ditentukan oleh manajemen, informasi yang ditampilkan menggambarkan apakah dokter mematuhi aturan yang sudah ditentukan.

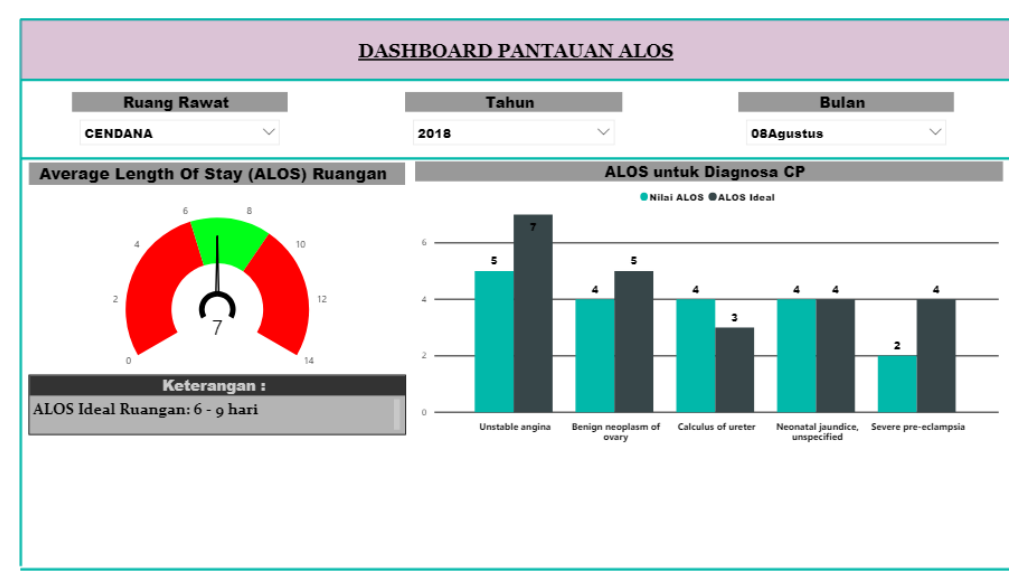

Gambar 7. Dashboard Kepatuhan Dokter Terhadap Pelayanan (LOS)

Visualisasi dashboard untuk pantauan terhadap angka kematian ditunjukkan pada gambar 8. Indikator yang ditampilkan adalah Gross Death Rate (GDR), Net Death Rate (NDR) dan informasi diagnosa dengan kasus kematian terbanyak. Indikator NDR dan GDR merupakan indikator yang berkaitan dengan angka kematian di Rumah Sakit, jika dikaitkan dengan informasi diagnosis tertentu dengan jumlah kematian terbanyak dapat digunakan oleh manajemen untuk menganalisis penyebab terbanyak kematian pasien dan dapat melakukan peningkatan pelayanan terhadap diagnosis penyakit tersebut untuk mengurangi angka kematian pasien. 


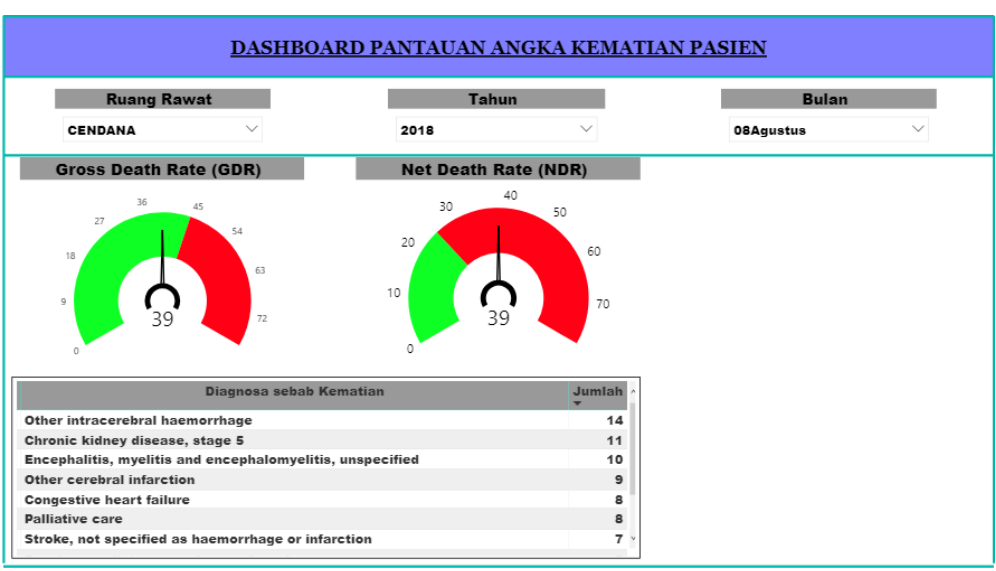

Gambar 8. Dashboard Pantauan Angka Kematian

Uji Coba implementasi dashboard BI dilakukan sebanyak 4 kali oleh manajemen. Tujuan implementasi ini dilakukan supaya sistem dapat di evaluasi dengan System Usability Scale (SUS). Kriteria dan aturan dalam metode SUS adalah metode SUS memiliki 10 pertanyaan dengan 5 pilihan jawaban yang memiliki skala penilaian likert, pertanyaan dengan nomor ganjil $(1,3,5,7,9)$ merupakan pertanyaan positif, pertanyaan dengan nomor genap $(2,4,6,8,10)$ merupakan pertanyaan negatif, setiap pertanyaan memiliki bobot nilai antara 0-4, pada pertanyaan-pertanyaan ganjil, skor setiap pertanyaan dihitung dengan cara bobot tiap pertanyaan dikurangi dengan nilai 1, pada pertanyaan-pertanyaan genap skor dihitung dengan cara 5 dikurangi bobot setiap pertanyaan, total skor didapat dengan menjumlahkan nilai akhir semua pertanyaan, dan total skor yang didapat dikalikan dengan 2.5 untuk mendapatkan skor SUS antara 0-100. Contoh proses penilaian kuesioner dengan mengikuti kriteria-kriteria tersebut dapat dilihat pada tabel 1 yang merupakan milik kepala bagian perencanaan.

Tabel 1. Perhitungan Kuesioner SUS

\begin{tabular}{|c|c|c|c|c|c|c|c|}
\hline$\overline{\mathrm{Nc}}$ & Pertanyaan & 1 & 2 & 3 & 4 & 5 & Penilaian \\
\hline & Saya sepertinya akan sering menggunakan sistem ini & & & & & $\mathrm{V}$ & $\begin{array}{l}\text { Nilai skala dikurangi } \\
\text { dengan } 1,5-1=4\end{array}$ \\
\hline 2 & $\begin{array}{l}\text { Saya melihat ada bagian fitur sistem ini yang merepotkan } \\
\text { yang mestinya hal itu tidak ada }\end{array}$ & $\mathrm{V}$ & & & & & $\begin{array}{l}5 \text { dikurangi nilai skala } \\
\qquad 5-1=4\end{array}$ \\
\hline & Saya rasa sistem ini mudah digunakan & & & & & $\mathrm{V}$ & $\begin{array}{c}\text { nilai skala dikurangi } \\
\text { dengan } 1,5-1=4\end{array}$ \\
\hline 4 & $\begin{array}{l}\text { Saya sepertinya akan membutuhkan bantuan teknisi agar } \\
\text { bisa lancar menggunakan sistem ini }\end{array}$ & & V & & & & $\begin{array}{l}5 \text { dikurangi nilai skala } \\
5-2=3\end{array}$ \\
\hline 5 & $\begin{array}{l}\text { Saya menemukan berbagai fungsi di sistem ini } \\
\text { diintegrasikan dengan baik }\end{array}$ & & & $\mathrm{V}$ & & & $\begin{array}{l}\text { nilai skala dikurangi } \\
\text { dengan } 1,3-1=2\end{array}$ \\
\hline 6 & $\begin{array}{l}\text { Saya menemukan terlalu banyak ketidaksesuaian dalam } \\
\text { sistem ini }\end{array}$ & & $\mathrm{V}$ & & & & $\begin{array}{l}5 \text { dikurangi nilai skala } \\
5-2=3\end{array}$ \\
\hline 7 & $\begin{array}{l}\text { Saya rasa orang-orang akan dengan cepat bisa } \\
\text { menggunakan sistem ini }\end{array}$ & & & & $\mathrm{V}$ & & $\begin{array}{c}\text { nilai skala dikurangi } \\
\text { dengan } 1,4-1=3\end{array}$ \\
\hline & Saya rasa sistem ini sulit untuk digunakan & $\mathrm{V}$ & & & & & $\begin{array}{l}5 \text { dikurangi nilai skala } \\
5-1=4\end{array}$ \\
\hline
\end{tabular}




\begin{tabular}{lcc}
\hline Saya merasa percaya diri untuk menggunakan sistem ini & v & $\begin{array}{c}\text { nilai skala dikurangi } \\
\text { dengan } 1,4-1=3\end{array}$ \\
\hline $\begin{array}{l}\text { Saya perlu belajar banyak hal terlebih dahulu sebelum } \\
\text { memulai menggunakan sistem ini }\end{array}$ & $\mathrm{v}$ & 5 dikurangi nilai skala \\
Total & $5-2=3$ \\
\hline Nilai & $33 \times 2.5=82.5$ \\
\hline
\end{tabular}

Perhitungan SUS score dilakukan dengan menjumlahkan nilai responden dibagi jumlah responden. Penilaian yang dilakukan oleh 11 responden menghasilkan perhitungan seperti tabel 2.

Tabel 2. Rekap Nilai Kuesioner SUS

\begin{tabular}{|c|c|c|c|c|c|c|c|c|c|c|c|}
\hline 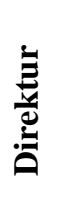 & 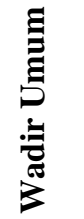 & 滰 & ర్ & 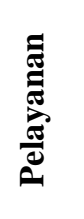 & 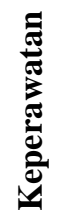 & $\underset{\Xi}{\Xi}$ & 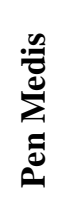 & 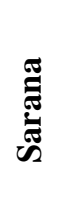 & 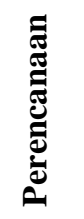 & $\stackrel{\Xi}{E}$ & Total \\
\hline 67,5 & 72,5 & 75 & 75 & 72,5 & 70 & 72,5 & 65 & 72,5 & 82,5 & 80 & 805.00 \\
\hline
\end{tabular}

Perhitungan nilai akhir, total nilai semua responden dibagi dengan jumlah responden dengan hasil perhitungannya adalah sebagai berikut:

$$
\text { Nilai Akhir }=\frac{805}{11}=73.18
$$

Nilai akhir yang diperoleh pada persamaan (1) dibandingkan dengan grafik percentile rank SUS score pada gambar 5 dengan kesimpulan sistem dengan nilai 73,18 berada dalam kategori baik dan layak untuk digunakan.

\section{KESIMPULAN DAN SARAN}

Kesimpulan yang diperoleh dari penelitian yang dilakukan adalah sebagai berikut:

a. Pengembangan Business Intelligence untuk membantu pengambilan keputusan di RSUD Prof. Dr. Margono Soekarjo Purwokerto dilakukan dengan melalui beberapa tahap pengembangan yaitu analisis data source (database SQLServer), pemodelan data warehouse, proses Extract, Transform, Load (ETL), Koneksi aplikasi Power BI dengan tabel fakta di data warehouse, dan perancangan visualisasi dashboard menggunakan Power BI.

b. Dashboard Business Intelligence dikelompokkan berdasarkan jenis pengambilan keputusan. Pertama dashboard manajemen tempat tidur yang berisi informasi nilai indikator BOR, BTO, TOI, dan jumlah pasien harian. Kedua yaitu dashboard pantauan kepatuhan dokter terhadap pelayanan (ALOS) atau clinical pathway yang berisi informasi nilai indikator ALOS Rumah Sakit dan ALOS untuk diagnosis Batu Ureter, Hiperbilirubin, CA Ovarium, Pre Eclamsia Berat, dan Unstable Angina Pactoris. Ketiga yaitu dashboard pantauan angka kematian yang berisi informasi nilai indikator NDR, GDR, dan diagnosis penyebab kematian terbanyak. 
c. Evaluasi sistem menggunakan usability testing. Tes kegunaan ini dilakukan sebelum sistem digunakan sepenuhnya oleh manajemen. Tes kegunaan menggunakan metode System Usability Scale (SUS) untuk mengetahui kualitas dan kelayakan aplikasi yang sudah dibuat.

d. Hasil evaluasi SUS memberikan hasil bahwa aplikasi yang dikembangkan mendapat nilai 73.18. Nilai tersebut termasuk dalam kategori layak jika merujuk pada grafik percentile rank penilaian SUS skor.

Adapun saran peneliti untuk penelitian lebih lanjut adalah perlu pengembangan terhadap pengambilan keputusan yang lain karena di Rumah Sakit banyak aspek yang perlu diatur oleh manajemen Rumah Sakit jika sistem elektronik sudah mampu dipakai di seluruh bagian. Informasiinformasi yang berkaitan dengan keuangan dan inventory dapat menjadi bahan pertimbangan untuk pengembangan selanjutnya.

\section{UCAPAN TERIMA KASIH}

Penelitian ini dilaksanakan dengan pendanaan penelitian bersumber dari dana pribadi peneliti. Peneliti mengucapkan terima kasih kepada semua pihak yang terlibat Rumah Sakit Prof. Dr. Margono Soekarjo Purwokerto beserta dosen pembimbing akademik Universitas Islam Indonesia Yogyakarta.

\section{DAFTAR PUSTAKA}

Abusweilem, M. A., \& Abualous, S. (2019). The impact of knowledge management process and business intelligence on organizational performance. Management Science Letters, 2143 2156. https://doi.org/10.5267/j.msl.2019.6.020

Azemi, N. A., Zaidi, H., \& Hussin, N. (2018). Information Quality in Organization for Better DecisionMaking. International Journal of Academic Research in Business and Social Sciences, 7(12), Pages 429-437. https://doi.org/10.6007/IJARBSS/v7-i12/3624

Cheng, C., Gilmore, T., Lougen, C., \& Stovall, C. (2018). Statistical Analysis, Data Visualization, and Business Intelligence Tools for Electronic Resources in Academic Libraries. What's Past Is Prologue: Charleston Conference Proceedings 2017. Dipresentasikan pada Charleston Conference. https://doi.org/10.5703/1288284316679

Eidizadeh, R., Salehzadeh, R., \& Chitsaz Esfahani, A. (2017). Analysing the role of business intelligence, knowledge sharing and organisational innovation on gaining competitive advantage. Journal of Workplace Learning, 29(4), 250-267. https://doi.org/10.1108/JWL07-2016-0070

Gaardboe, R., Nyvang, T., \& Sandalgaard, N. (2017). Business Intelligence Success applied to Healthcare Information Systems. Procedia Computer Science, 121, 483-490. https://doi.org/10.1016/j.procs.2017.11.065

Gaardboe, R., \& Svarre, T. (2017). Critical Factors For Business Intelligence Succes. In Proceedings of the 25th European Conference on Information Systems (ECIS), Guimarães, Portugal, June 5-10, 2017 (pp. -). ISBN 978-989-20-7655-3 Research Papers 
Gowthami, K. dan M. R. Pavan Kumar. (2017). Study on Business Intelligence Tools for Enterprise Dashboard Development. International Research Journal of Engineering and Technology (IRJET), 04(04). 2987-2992

Khedr, A., Kholeif, S., \& Saad, F. (2017). An Integrated Business Intelligence Framework for Healthcare Analytics. International Journal of Advanced Research in Computer Science and Software Engineering, 7(5), 263-270. https://doi.org/10.23956/ijarcsse/SV7I5/0163

Kruse, C. S., Stein, A., Thomas, H., \& Kaur, H. (2018). The use of Electronic Health Records to Support Population Health: A Systematic Review of the Literature. Journal of Medical Systems, 42(11), 214. https://doi.org/10.1007/s10916-018-1075-6

Lee, C. H., \& Yoon, H.-J. (2017). Medical big data: Promise and challenges. Kidney Research and Clinical Practice, 36(1), 3-11. https://doi.org/10.23876/j.krcp.2017.36.1.3

Llave, M. R. (2019). A Review of Business Intelligence and Analytics in Small and Medium-Sized Enterprises: International Journal of Business Intelligence Research, 10(1), 19-41. https://doi.org/10.4018/IJBIR.2019010102

Loewen, E. (2017). Business intelligence: Assimilation and outcome measures for the health sector. University of Victoria, School of Health Information Science

Izhariman, L., Darwiyanto, E., \& Puspitasari, S. Y. (2017). Perancangan Executive Information System Rumah Sakit Untuk Evaluasi Kinerja Pelayanan Di Rsup Mohammad Hoesin Palembang. e-Proceeding of Engineering, 4(3), 4957.

Kiani Mavi, R., \& Standing, C. (2018). Cause and effect analysis of business intelligence (BI) benefits with fuzzy DEMATEL. Knowledge Management Research \& Practice, 16(2), 245-257. https://doi.org/10.1080/14778238.2018.1451234

Silvana, M., Ricky, A., \& Derisma. (2017). Pengembangan Model Business Intelligence Manajemen Rumah Sakit untuk Peningkatan Mutu Pelayanan. Jurnal Edukasi dan Penelitian Informatika Untan, 3(2). https://doi.org/10.26418/jp.v3i2.22833

Trieu, V.-H. T., Cockcroft, S., \& Perdana, A. (2018). Decision-Making Performance in Big Data Era: The Role of Actual Business Intelligence Systems Use and Affecting External Constraints. Research-in-Progress Papers ECIS 2018 Proceedings, 12

Vayena, E., Dzenowagis, J., Brownstein, J. S., \& Sheikh, A. (2018). Policy implications of big data in the health sector. Bulletin of the World Health Organization, 96(1), 66-68. https://doi.org/10.2471/BLT.17.197426

Vokshi, B. N. (2017). Role of Accounting Information in Decision- Making Process, the Importance for its Users. 2017 ENTRENOVA Conference Proceedings, 8. 